\title{
EXPLAINING THE EMERGENCE ORDER OF CONTACT-INDUCED LANGUAGE CHANGE PHENOMENA IN LANGUAGE MAINTENANCE
}

\author{
Anna Verschik \\ Tallinn University
}

\begin{abstract}
According to generalizations made by Thomason and Kaufman (1988), contact-induced language change in language maintenance starts from the lexicon, then progresses to semantics, phonology, non-core morphosyntax and may result in a profound restructuring. To date no explanations for this particular order have been suggested. The article "translates" the borrowing scale into the metalanguage of the code-copying framework (Johanson 1992), which views contact-induced language change in lexicon, meaning and structure within the same terminological framework. This terminology enables the view that the cognitive mechanism is the same (copying), only that different types of meaning (specific vs. abstract) produce different types of copies. Specific or expressive items yield global copying, while more abstract meaning (grammatical) yields selective copying. Apparently, processing, entrenchment and conventionalization of more abstract meaning require more time than in the case of specific or expressive meaning. This explains why structural changes (selective copies) appear later.
\end{abstract}

Keywords: contact-induced language change, code-copying, structural change, Estonian, Russian, English

\footnotetext{
1 The research was funded by the Ministry of Education and Research of the Republic of Estonia, grant EKKD33 "Data and corpora of Estonian children and youth multilingual communication”.
} 


\section{Introduction}

It is well known that there are no pure, completely isolated languages. Languages, or more precisely, their speakers, engage in encounters with each other, which leads to mutual influence and subsequent changes in the languages involved. The most common result is lexical borrowing (words) and structural change (meaning, patterns, order of elements, grammatical structures, etc.). In contact linguistics, such change is often referred to as contact-induced language change (henceforth "CLIL"). Changes occur in both directions: the impact L1 > L2, is often the focus of second language acquisition studies and language pedagogy (and, to a lesser extent, of contact linguistics), while the impact of L2 $>\mathrm{L} 1$ is mostly of interest to contact linguistics. In the former case, the main mechanism is often called interference, or transfer: patterns, rules, combinations from $\mathrm{L} 1$ are carried over to L2. In the latter case (L2 > L1), the prevalent mechanism is borrowing in a broader sense, that is, import (or copying) of lexicon, meanings, rules, etc. into L1. The situation where speakers not only acquire L2 but abandon their L1 is referred to as language shift. If the impact of L1 > L2 is generalized in a community of speakers, this is sometimes called shift-induced interference. However, while changes are bidirectional and individuals may decide to maintain their language or to shift to another one, it is relevant on a broader sociolinguistic scale which of the two scenarios prevails. In this article, I will concentrate on language maintenance and L2 impact on L1.

A series of generalizations as to the order in which CLIC phenomena occur was a major breakthrough in the field (Thomason, Kaufman 1988). The aim of the current article is to address the question of why CLIL phenomena tend to appear in this particular order in a language maintenance situation. In their now classical study, Thomason and Kaufman (1988) suggest that in language maintenance and language change situations two different mechanisms are at play (borrowing vs. shift-induced interference respectively), and 
changes start in different subsystems of the language. In a language maintenance situation, which is the situation under consideration in this article, changes start from the lexicon (i.e., lexical borrowing), then slight changes in semantics, prosody and phonology and noncore morphosyntax may appear (Thomason, Kaufman 1988; Thomason 2001). Of course, this may not be the case if purism in language planning, monolingual language ideologies and speakers' negative attitudes to foreignisms are at play (Aikhenvald 2007, Thomason 2007: 48). This also may be different for contacts between closely related varieties that share a lot of material similarity and structure. For the sake of simplicity such instances are not considered here.

These observations and generalisations by Thomason and Kaufman (1988), developed further by Thomason (2001), have a solid empirical basis derived from a wide range of contact situations. However, I am not aware of any systematic attempts of explanation as to why CLIL in language maintenance emerges and appears in this particular order, that is, starting in the lexicon and spreading to semantics and morphosyntax. Some suggestions have been formulated by Verschik and Kask (2019), based on a case study of English-Estonian language contacts. The present paper seeks to take this further and to suggest an explanation that is rooted in cognitive contact linguistics (usage-based approach as suggested by Backus 2012, 2014, Zenner et al. 2019, and Verschik 2019).

I suggest that the type of meaning of a linguistic item or pattern (specific, figurative, grammatical, etc.) matters for the order of appearance of CLIL phenomena, usually referred to as lexical borrowing, structural borrowing, loan translations, convergence, etc. My main assumption is that different types of meaning require different amounts of time for processing and entrenchment (i.e., becoming rooted in an individual's cognition; see Backus 2015, Zenner et al. 2019). To distinguish between the degree of specificity/abstractness of meaning, I am using the code-copying framework (henceforth CCF), developed by Johanson (1992, 2002a, 2002b). CCF views all types of CLIL using the same metalanguage for all linguistic 
subsystems (lexicon, semantics, morphosyntax) and appears to be descriptively accurate (Backus, Verschik 2012). Although CCF is formulated in structural terms, it is compatible with the principles of cognitive contact linguistics (Verschik 2019), where meaning is placed centre stage (Backus, Verschik 2012), and helps to highlight differences in copying of linguistic items with various types of meaning.

The data used for generalizations comes from three different sources: studies on the impact of Estonian on indigenous Russian; the current impact of Estonian on the Russian of the Soviet-time newcomers and their descendants; and the current impact of English on Estonian. I will explain below how data from these contact situations may be relevant for the explanations of the order of CILC. As there are no corpora for the former two contact situations and a corpus of English-Estonian bilingual language use is currently being built, I use data from earlier literature, as well as from my own research on the present CILC in Estonia's Russian and the impact of English on Estonian.

The structure of the article is as follows. First, I briefly present the scale of CLIL (Thomason 2001; Thomason, Kaufman 1988). Then basic terms and procedures of CCF are explained, and an outline of how various types of copying correlate with various linguistic items is proposed. After that, empirical data on CLIL phenomena from various contact situations in Estonia with different duration are discussed: Estonian impact on the indigenous (old settlers') Russian varieties (from $17^{\text {th }}$ century on), Estonian impact on modern Russian (that is, Soviet era newcomers and their descendants, starting from the 1990s), English impact on Estonian (roughly from the mid-1990s). Finally, it is suggested that different types of meaning require a different degree of cognitive effort to be copied and internalised, and this different speed of processing and internalisation of different types of meaning explains the order of appearance of CLIL phenomena. 


\section{CLIL in language maintenance}

Language maintenance does not imply preservation of a variety without any change; it only means that a group of language users does not abandon their L1 and does not shift to another language. No matter how L1 may change under the impact of L2, for laypeople it is still the same language. Thomason and Kaufman (1988) and later Thomason (2001: 70) proposed a borrowing scale where extra-linguistic factors such as intensity of contact, the size of a bilingual group, spread of bilingualism, language proficiency, attitudes, social factors favouring borrowing, etc. correlate with what is borrowed. The scale offers a description of what kind of borrowing is to be expected at what stage of contacts. It has to be noted that the term "borrowing" is used in a broad sense and includes borrowing of meaning, patterns, and structure and does not exclusively refer to lexical borrowing.

Thomason (2001: 70-71) suggests four stages in her scale (see Table 1). For each stage she describes what kind of CLIL takes place in lexicon and structure.

It is clear that in reality it is rather a continuum than clearly definable discrete stages: some diagnostic features may belong to one stage and others to the next. For instance, indigenous Russian varieties in Estonia exhibit some changes in phonology, such as substitution of the combination of palatalized consonant and $a, o$ with the Estonianlike combination of non-palatalized consonant and front vowel $\ddot{a}, \ddot{o}$ (Russian z'at' 'son in law' is realized like zät', Heiter 1968: 107). This feature is characteristic of Stage 3. However, no radical restructuring in core morphosyntax, such as compulsory change of word order or borrowing of inflectional morphology occur in that variety, so in this respect the contact situation belongs to Stage 2. As Thomason (2001: 71) emphasizes, any borrowing scale is a matter of probabilities and not possibilities. Still, in general terms, the order from lexicon via semantics and non-core morphosyntax towards more serious structural borrowing is confirmed with solid empirical evidence (see examples in Thomason 2001; Thomason, Kaufman 1988). 
Table I. Stages of CLIL (based on Thomason 200I: 70-7I).

\begin{tabular}{|c|c|c|c|}
\hline $\begin{array}{l}\text { Stage } \\
\text { no }\end{array}$ & $\begin{array}{c}\text { General } \\
\text { description }\end{array}$ & $\begin{array}{l}\text { Changes in } \\
\text { lexicon }\end{array}$ & Changes in structure \\
\hline $\begin{array}{l}\text { Stage } \\
1\end{array}$ & $\begin{array}{l}\text { Casual contact, } \\
\text { few fluent bilingual } \\
\text { speakers, the } \\
\text { community of } \\
\text { borrowers does not } \\
\text { have to be fluent } \\
\text { in L2. }\end{array}$ & $\begin{array}{l}\text { Borrowing of non- } \\
\text { basic vocabulary, } \\
\text { mostly nouns but } \\
\text { also verbs, adverbs } \\
\text { and adjectives. }\end{array}$ & None \\
\hline $\begin{array}{l}\text { Stage } \\
2\end{array}$ & $\begin{array}{l}\text { Slightly more } \\
\text { intensive contact, } \\
\text { more fluent bilingual } \\
\text { speakers but they } \\
\text { are still a minority. }\end{array}$ & $\begin{array}{l}\text { Also function } \\
\text { words (particles, } \\
\text { conjunctions) are } \\
\text { borrowed; still no } \\
\text { basic vocabulary is } \\
\text { borrowed. }\end{array}$ & $\begin{array}{l}\text { Minor structural borrowing } \\
\text { that does not alter the type of } \\
\text { LI structures (new phonemes } \\
\text { in borrowed lexicon, new } \\
\text { functions for existing structures, } \\
\text { increase in the usage of existing } \\
\text { marginal patterns). }\end{array}$ \\
\hline $\begin{array}{l}\text { Stage } \\
3\end{array}$ & $\begin{array}{l}\text { More intense } \\
\text { contact, } \\
\text { sociolinguistic } \\
\text { setting favours } \\
\text { borrowing. } \\
\text { Also non-core } \\
\text { vocabulary and } \\
\text { moderate structural } \\
\text { borrowing. }\end{array}$ & $\begin{array}{l}\text { More borrowing, } \\
\text { including closed- } \\
\text { class items } \\
\text { (pronouns, } \\
\text { low numerals); } \\
\text { derivational affixes } \\
\text { are used not only } \\
\text { with borrowed but } \\
\text { also with native } \\
\text { stems }\end{array}$ & $\begin{array}{l}\text { More borrowing but without } \\
\text { an overall change of typological } \\
\text { characteristics of LI. Loss of } \\
\text { some native phonemes; new } \\
\text { prosodic features like stress } \\
\text { placement, morphophonemic } \\
\text { rules, etc. Radical changes } \\
\text { in word order, borrowed } \\
\text { inflectional morphology, changes } \\
\text { in syntax of coordination and } \\
\text { subordination. }\end{array}$ \\
\hline $\begin{array}{l}\text { Stage } \\
4\end{array}$ & $\begin{array}{l}\text { Intense contact, } \\
\text { bilingualism is } \\
\text { common for the } \\
\text { speakers of LI, } \\
\text { social circumstances } \\
\text { favour borrowing. }\end{array}$ & $\begin{array}{l}\text { Heavy lexical } \\
\text { borrowing }\end{array}$ & $\begin{array}{l}\text { "Anything goes"; major } \\
\text { typological changes } \\
\text { occur (addition or loss of } \\
\text { morphological categories, } \\
\text { restructuring of phonology, } \\
\text { major changes in word order, } \\
\text { transition from agglutinating to } \\
\text { fusional type or vice versa). }\end{array}$ \\
\hline
\end{tabular}

Several clarifying points need to be added. The scale includes conjunctions (Stage 2 under lexicon) but not discourse words. According to some scholars (Salmons 1990, Matras 1998 and references therein), discourse words together with conjunctions form a separate class of items, labelled differently by different scholars (discourse particles, pragmatic particles, etc.). In my opinion, Matras' 
(1998) term "utterance modifiers" clarifies the nature and the function of items belonging to this class: they modify utterance without changing the meaning of the proposition itself. Wertheim (2003: 214-217) includes borrowing of utterance modifiers into the list of diagnostic features of various stages of CILC because borrowed utterance modifiers may be an indication of a "contracting minority language", as she calls it.

Matras $(1998,2009)$ provides a cognitive explanation for the borrowing of utterance modifiers and assumes that they come from a pragmatically dominant language (that is, the language that is dominant in organizing and shaping the discourse, which may differ from the sociolinguistically-dominant languages). He also shows that the meaning and function of utterance modifiers (shaping and modifying the discourse, showing speakers' attitudes) make them susceptible to borrowing. This is a relevant observation that will be discussed below.

Another reservation concerns the term "borrowing" itself. Even if we assume that it can be used in relation to structure and not only content words, as Thomason (2001) does, it is imprecise and too broad. In the next section I discuss the need for a holistic model that describes all types of CLIL under the same umbrella and allows for a more precise distinction between various changes in structure.

\section{In search of a model}

\section{I. GENERAL CONSIDERATIONS}

Although Thomason (2001) uses the term "borrowing" in a broad sense, the term is often reserved for the cases when overt foreign material appears in another language. Other instances when a seemingly monolingual utterance is in fact multilingual are described as "convergence", "structural change", "loan translation", etc. This terminological division has been criticised (Backus, Verschik 2012) because the split in metalanguage creates an impression that contact-induced innovations and changes in lexicon vs. other language 
subsystems are of a fundamentally different nature. In fact, evidence from various language pairs demonstrates that lexicon and morphosyntax are not cognitively separated and insertion of lexical items from another language may cause morphosyntactic restructuring (Backus 2005). It has also been reported in the literature that in some contact situations nouns are likely to be "borrowed" in the classical sense, while verbs tend to be so-called semantic extensions (Backus, Verschik 2012).

However, there are in-between instances that are neither purely "borrowing", that is, import of a form-meaning complex, not involving structural or semantic change. Consider Example (1), English is in bold:

(1) Estonian

hard-töötav 'hard-working'

cf. English hardworking

While the combination of the items and the overall meaning is replicated from English (pattern replication), one element in the combination hard is replicated as a whole (form + meaning, matter replication). Since hardworking is a conventionalized combination of items, it would be counterintuitive to analyse hard separately as "borrowing” and töotav 'working' as what is often called loan translation.

Another observation is that not all types of structural change are alike. Consulting the scale (Thomason, Kaufman 1988; Thomason 2001), it seems that a more precise terminological distinction is needed in order to differentiate between pattern replication of, say, fixed expressions and of argument structure. This will be discussed in more detail in Section 3.2.

This means that a more precise metalanguage for various types of pattern replication is needed. One may ask why yet another terminological framework needs to be introduced alongside existing ones. After all, usage-based approaches that are also referred to in this study do not presuppose clear-cut categories. While I agree that 
oftentimes contact linguistic phenomena are in the in-between zone and simply cannot be described in straightforward terms, I think that a choice of metalanguage is important because metalanguage may help to shed light on phenomena that may otherwise remain obscure. First, the conceptualization of CILC as the same cognitive process (replication or copying) is relevant. Second, Example (1) and similar are in-between and appear systematically in certain type of lexical items (compound nouns, analytic verbs, fixed expressions) and have to be analysed as a separate category. CCF, developed by Johanson $(1992,1993,1999,2002 a, 2000 b)$ is a theoretical framework that provides metalanguage for description of instances like (1) and allows to develop metalanguage for distinction between (2), (3) and (4).

\section{2. $\mathrm{CCF}$}

CCF was developed by Johanson (1992, 1993, 1999, 2002a, 2002b). Like Matras and Sakel (2007), he suggests that there is a single mental process behind different contact phenomena, namely, copying (replication in Matras and Sakel's terms). He finds that borrowing, import, transfer, etc. are erroneous metaphors that obscure the picture: nothing is taken away from one language and carried over to another. Unlike many formal models, this framework is not constraint-based; CCF takes sociolinguistic and cognitive factors into consideration. Copying may occur from a sociolinguistically-dominant code, or model code, into the basic code (usually, a minority or immigrant variety) but is also possible in the opposite direction. Copying from L1 to L2 is called "imposition" and copying in the opposite direction, from L2 to L1, is called "adoption". This paper focuses on adoption (L2 impact in language maintenance situation). The basic postulates of CCF are presented as follows:

- A copy may preserve all properties of the original but it is not the original; it lives its own life in the basic code. 
- CCF applies the same terminology for CILC in lexicon, semantics and morphosyntax. It appears to be unproductive to look separately at code-switching (i.e., overt otherlanguage items and chunks) and structural change because the two are interconnected (Backus 2005). An item from another language may change morphosyntax of the clause or word order. Therefore, there is no strict cognitive separation between lexicon and morphosyntax, and it would be wise to us the same terminological framework.

- CCF does not draw a sharp border between synchronic and diachronic processes. There is no reason to suggest that CILC as such was radically different in the past.

- A copy can gain currency and become habitualized and later conventionalized. The degree of adaptation (phonetical, morphological, etc.) is not a criterion for distinction between what is called code-switching and borrowing. Bilinguals are not a sum of two monolinguals and do not necessarily need the same mechanisms of adaptation.

- Attractiveness and salience. Some items are salient (prominent at cognitive level). These are attractive for copying. For instance, it has been attested that analytic transparent forms are attractive. Similarity, material or structural, makes copying more likely as well.

- Last but not least, the unified metalanguage allows us to assume that the cognitive mechanism behind CLIC is the same, i.e., copying. The question is then not "what can be borrowed and why?" but rather "what kind of linguistic items are susceptible to what kind of copying and why?".

CCF subdivides bilingual speech (code interaction) into two groups: code alternation that more or less corresponds to alternations in other models (Muysken 2000), that is, when an entire clause is in another variety, and code copying proper. I will not consider alternations because they are irrelevant for the present discussion. 
Any linguistic element has four kinds of properties: material, semantical, combinational and frequential. One may copy all four or just some of them. If all properties are copied, it is called a "global copy" (GC). It corresponds to code-switching and borrowing in conventional terminology. For instance, the English verb to like yields Estonian laikima 'to like (on social media)'. The English stem is copied onto Estonian and necessary inflections are added.

If only some properties are copied, the result is a "selective copy" (SC). This group may be rather diverse. Johanson does not explicitly subdivide this group but occasionally mentions semantic copying (Johanson 1993: 212, Johanson 2002b: 263), which corresponds to calques or loan translations. All types of selective copying are connected to frequency: unlike other overt language items (lexemes, multiword items), structural features are less noticeable but are more frequent in the input (Backus, Verschik 2012; see also discussion in Section 5.2).

I suggest applying these and some other labels to SCs in a consequent manner. Material copying would then be copying of phonological properties (realization of phonemes, new combination of phonemes, prosody or realization of common internationalisms; one such example was discussed in Section 2). Semantic copying is what is sometimes called "semantic extension". I apply this term to single items only, as in (2); for multi-word items another term is reserved.

(2) modern Russian

krasivaja pogoda

'nice weather'

cf. Estonian ilus ilm 'nice/good weather'

cf. Standard Russian xorošaja pogoda 'good weather'

Example (2) is a selective semantic copy where the Russian adjective krasivaja 'nice, beautiful' has the meaning of Estonian ilus 'nice, beautiful, good, appropriate'. In Standard Russian, the adjective can only be applied in the sense of 'beautiful picture', 'beautiful outfit', 
etc. but not 'nice weather', while Estonian ilus has a broader range of meanings.

Example (3) below may be uncommon in monolingual Russian but it is semantically transparent and does not sound ungrammatical. It is an instance of selective combinational copying, that is, both a combination of elements in an expression as well as its complex meaning are copied. This type also corresponds to calques or loan translations but it is useful in order to distinguish between cases such as (2) and (3) because the latter appears more complex.

(3) modern Russian $s$ belogo lista 'from a clean slate'; literally, 'from white page' cf. monolingual Russian s čistogo lista, literally, 'from clean page' cf. Estonian puhtast lehest, literally, 'from white page'

Example (4) demonstrates selective combinational copying as well. However, it is something between (3) and (5) as far as grammaticality in monolingual Russian is concerned. In (3), no grammatical rules of monolingual Russian are violated. Example (4) sounds strange and unintelligible because the lexical items are not combinable in this way, although no grammatical rules are violated.

(4) modern Russian vyučil v golovu 'learned by heart', literally, 'learned into the head' Cf. monolingual Russian vyučil naizust'/na pamjat' 'learned by heart', literally, 'learned out of lips/onto memory'

Cf. Estonian õppis pähe 'learned by heart', literally, 'learned into the head'

It also has to be noted that (3) is a selective combinational copy of a unique idiom, whereas (4) demonstrates copying of an idiomatic analytic verb. Copying of Estonian analytic verbs both in the old settlers' variety and in modern Russian is quite common (Heiter 1977, Verschik 2008: 135 ff.), as well as copying of Estonian compound nouns. Thus, here, unlike in (3), we deal with copying of an item belonging to a certain class and not being a unique expression. 
The combination of items copied in (3) is unique, while that in (4) is more general and other Estonian analytic verbs have been copied into Russian as well.

Example (5) differs from (2), (3) and (4) because the meaning is transparent (not idiomatic or metaphoric) but the argument structure is copied from Estonian; thus, combinability rules and functions of grammatical cases are changed. Verbs with the meaning "to envy, "to believe", "to disturb", etc. require partial object (partitive) in Estonian and dative in Russian (that is, literally, "believe to whom"). In (5) Russian direct object case (accusative) is used instead of dative.

(5) old settler's Russian

$\begin{array}{llll}\mathrm{Ne} & \text { verj-u } & \text { ja } & \text { vas } \\ \text { NEG } & \text { believe-1SG } & \text { I } & \text { you:GEN.PL }\end{array}$

'I don't believe you'

(modified from Nemčenko 1974: 128)

Cf. monolingual Russian

$\mathrm{Ne}$ verj-u ja vam

NEG believe-1SG I you:DAT.PL

'I don't believe you' (literally, 'to you')

Cf. Estonian

$\begin{array}{llll}M a & \text { ei } & \text { usu } & \text { te-i-d } \\ \text { I NEG } & \text { believe } & \text { you-PL-PART } \\ \text { 'I don't believe you' }\end{array}$

Copying in (5) is referred to as combinational copying (Johanson 1993: 213). Example (5) sounds ungrammatical in monolingual Russian.

Finally, I suggest distinguishing copying of grammatical meaning/function as a separate group. Sometimes these are explicitly frequential copies because the number of contexts where a construction or a form occurs is increased according to the model code (similarly, Heine and Kuteva (2005: 44-75) talk about a minor use 
pattern changing into a major use pattern). I believe that these copies should be considered separately from semantic copies because in this case one deals with the extension of grammatical meaning rather than of meaning of particular lexical items as in Example (2). Consider the use of the Estonian mas-construction (the inessive case of ma-infinitive), modelled on the English progressive:

(6) Estonian

Ma ole-n täna spas-sse mine-ma-s
I be-1SG today spa-ILL go-INF-INES
'I am going to the spa today'
(modified from Verschik and Kask 2019)
Cf. monolingual Estonian

Lähe-n täna spaa-sse

go-1SG today spa-ILL

Cf. English I am going to the spa today

Example (6) demonstrates how the existing pattern in Estonian that is used in a limited number of contexts gains more currency under the impact of English (more in Metslang 2006, also discussion in Backus and Verschik 2012).

Deletion of differences may also be a copy of this type (that is, non-distinction from the model code is copied). For instance, fading of aspectual opposition in the old settlers' Russian variety under the impact of Estonian (Mürkhein 1968: 177) belongs to this type of selective frequential copying/copying of functions.

An intermediate type of copies between GC and SC is called "mixed copy" (MC). Analytic forms, expressions, compounds, etc. may be subject to mixed copying. The overall meaning and the combination of items are copied selectively and one of the elements is copied globally. Thus, hard-töötav 'hard-working' from Example (1) is an MC. Earlier I explained why analysing every component separately would be unreasonable. Moreover, as it will be shown below, it is relevant what component in a multi-word item is copied globally. 
In the next sections I will turn to the question formulated earlier: what kind of linguistic items is subject to which type of copying?

\section{Correlation between types of copying and types of linguistic items}

In the literature on borrowing and, especially, in borrowing hierarchies (Field 2002; Van Hout, Muysken 1994), nouns are described as primary candidates for borrowing. The sequence of other parts of speech may vary: some researchers place verbs before adjectives and some do the opposite, but as far as nouns are concerned, they always take the first position. Traditional borrowing hierarchies focus on borrowing of form + meaning combinations (parts of speech and morphemes), that is, GCs in Johanson's terms, in this way drawing a border between GS and the rest of CILC. If, however, we consider CILC in semantics, morphosyntax, etc. together with lexical changes, we notice that global copying occurs when an element has a specific, particular meaning. Backus (2001) introduces the notion of semantic specificity, which explains why what we refer to as a GC is attractive for copying. These are concrete, often term-like lexical items. Nouns whose primary function is nomination (naming things and phenomena) are more specific than other parts of speech.

As for verbs, they may be globally copied (Estonian laikima 'to like (on social media)', mentioned previously) but at least in some contact situations, for instance, that of modern Russian in Estonia, there are relatively few GCs of Estonian verbs and rather more SCs. One reason for this is that verbs are more "structured" (recall highly complex verb systems in synthetic languages), but this is not a universal explanation, because verb may be more "structured" in the model code and less in the basic code (see discussion on classification of "borrowed" verbs in Verschik 2008: 94 ff.). Another explanation lies in meaning: except for specific, term-like verbs, the meaning of verbs tends to be more abstract. Thus, when one speaks about "borrowing" of verbs, assuming lexical borrowing only, one may 
overlook the fact that in some contact situations, verbs are subject to selective copying rather than global. This is an example illustrating why unified terminological framework is useful: if verbs are not "borrowed", it does not mean that CILC does not occur in verbs.

Utterance modifiers, mentioned in Section 2, yield GCs, although SCs occur sometimes as well when there is material similarity between items in two languages (Keevallik 2006a, 2006b; Verschik 2008: 165). A sociolinguistic explanation (sociolinguistic dominance, identity marking, etc.) for copying of utterance modifiers is valid but only to a certain extent. Matras (1998) suggests that because of their function to shape and direct discourse, having one set of them helps to relieve any cognitive pressure a bilingual speaker may experience. A reason for copiability of utterance modifiers is their perceptual salience: prominence in discourse, emphatic stress, information packaging (for instance, marking a new topic) (Backus, Verschik 2012).

Speaking of expressivity, adjectives referring to emotions or conveying speakers' attitudes are often subject to global copying. Consider rendering the difficult-to-translate Estonian uimane 'slow and sleepy (state or feeling, person)' into modern Russian or the English adjectives freaky, insane, scary and similar in Estonian (Verschik, Kask 2019).

Idiomatic or fixed expressions may be copied globally (or may be a code alternation, if such an expression is a syntactically autonomous unit) or selectively. What makes them attractive for copying is their figurative meaning. Example (7) is a code alternation and demonstrates an overt use of material from English.

(7) Aga mul lihtsalt pea valutab ja hirmsasti tahaks magada, aga lihtsalt ei onnestu. I am crying on the inside.

'but I just have a headache and terribly want to sleep but cannot. I am crying on the inside' (Verschik 2019: 75) 
In (8), a fixed expression is an SC (semantic combinational copy), a word for word rendition from English into Estonian:

(8) nagu poleks homset

'like there is no tomorrow'

(modified from Verschik and Kask 2019: 14)

The meaning of idioms is specific and unique. Idioms tend to be salient for L2 speakers but are unmarked for L1 speakers (see discussion in Kecskés 2006). Even if L2 speakers realize that they are dealing with an idiom and that there might be an equivalent in L2, the figurative meaning and novelty makes idioms attractive. At this point, it is difficult to predict in what cases global copying and in what cases selective copying of idioms is preferred (apart from pragmatic reasons that condition either a monolingual or multilingual mode).

Compared to specific or expressive meaning and pragmatic prominence, which can also be considered to be specific, instances such as (4), (5) and (6) all demonstrate copying of something abstract: combination and complex meaning in a certain type of items such as analytic verbs in (4); combinability rules in (5); function and frequency of usage in (6).

As for (2), which is a semantic copy, one may say that this is a particular meaning of a particular Estonian lexical item copied into Russian; however, that is not the whole picture. While global copying of a specific item either introduces a new meaning (uimane 'sleepy and slow') or helps to distinguish between different meanings (laikima 'to like (on social media) is more particular than just 'to like'), selective semantic copying in single lexical items works in the opposite direction, i.e., the meaning becomes broader and less particular. This is why sometimes the term "semantic extension" is used in traditional terminology.

Clearly, copying of word order, argument structure or function cannot be explained by specificity. Backus and Verschik (2012) suggest that frequency may be a reason for selective copying rather than 
specific meaning. Indeed, order of elements, and their combinability rules, etc. are abstract and have a very general meaning, unlike lexical items with their specific meaning. Due to this, grammatical patterns are not as noticeable as overt linguistic items are, but occur more frequently in the input - think of any lexical item and compare it to, say, the use of progressive in English. While GCs are prominent and selected consciously, selective copying occurs subconsciously. Similarly, Backus and Verschik (2012) observe that words and morphemes are more noticeable (overt foreign language elements) than patterns.

Mixed copying as in Example (1) and Examples (11) and (12) below is an intermediate type between global and selective copying. A similar notion of loan blends was suggested by Haugen (1972: 85) but remained underdeveloped. Estonian-Russian data suggest that Estonian compound nouns and analytic verbs are likely candidates for mixed copying. By definition, mixed copying can only occur in a multi-word item (expression, compound, etc.). Consider Examples (11) and (12) - English is in bold and Russian is underlined:

(11) English $>$ Estonian

smart fabrics $>$ smart-kangad

(modified from Rästa 2020: 54)

(12) Estonian > modern Russian

voz'mi salat kõrvale 'add some salad'

Cf. Estonian kõrvale võtma, literally 'take onto the side'

Example (11) is also theoretically an instance of a SC as there exists an exact equivalent in Estonian nuti- 'smart' (cf. nutitelefon 'smartphone'), so it would be nutikangad 'smart fabrics'. Still, most young Estonians are fluent in English and use it on daily basis, so if there are no genre constraints (monolingual genre like a newspaper article, etc.), both options exist.

As for (12), Russian does not have the same kind of analytic verbs as Estonian has. Estonian analytic verbs, both idiomatic and 
semi-idiomatic, can yield SCs and MCs in Russian. There may be variation between selective and mixed copying in the same analytic verb (Verschik 2008: 147). However, I believe that the verb kõrvale võtma 'to add (food, etc.)' cannot (yet) be copied selectively because the particle korrvale '(on)to the side' is not very well translatable into Russian. Theoretically, it may be rendered as na storonu 'onto the side' but that sounds strange and, apparently, acceptance and conventionalization of such an item requires more time. The reasons for mixed copying do not boil down to untranslatability of one of the components, as the discussion of Example (11) demonstrates. What is relevant is that in all instances of mixed copying, the component that is globally copied renders the meaning more specific: kõrvale võtma 'to add' is more specific than võtma 'to take'; and smartkangad 'smart fabrics' is more specific than kangad 'fabrics'. Taking into consideration the connection between semantic specificity and global copying, this appears entirely logical.

In principle, multi-word items (compounds, fixed expressions, analytic verbs, idioms) have a potential for all types of copying. As said above, sometimes the choice of MC is conditioned by untranslatability; sometimes the choice depends on the type of interaction, genre (monolingual or multilingual), etc.

Thus, our understanding of meaning should include not only lexical or semantic meaning but also more abstract types: functional and grammatical meaning. Some types of meaning favour global copying and others selective copying. Mixed copying calls for more investigation in different language situations.

In the next section I will briefly discuss the impact of Estonian on the old settlers' and modern Russian and the impact of English on Estonian in the light of copying of specific vs. abstract meaning. 


\section{Analysis of CLIL in three contact situations in Estonia}

Looking into the order of various types of copying in different contact situations may be instructive. Of course, the establishment of the order is difficult or impossible if CILC has already occurred and is conventionalized, and there are no sources of the pre-contact variety. The three contact situations may be illustrative for the following reasons. First, in the case of old settlers' Russian and modern Russian we have different starting point of the contacts with Estonian and different sociolinguistic profiles of Russian speakers; therefore, one may be able to compare the impact of Estonian and to observe similarities and differences in the types of copying. Besides, there are monolingual varieties of Russian (in Russia) that also provide a basis of comparison. Second, English impact on Estonian is fairly recent and is happening right now, while the pre-contact state of Estonian is known. In what follows I briefly present a description of the three situations.

Russian old settlers appeared in what is modern Estonia at various times, the most prominent group being the Old Believers, who escaped religious persecutions and found a refuge in Estonia in the $17^{\text {th }} \mathrm{c}$. (Külmoja 2004 and references therein). They preserved some features of the Pskov variety of Russian and at the same time became bilingual. For a relatively long time, they were isolated from other regional varieties of Russian and Standard Russian. This changed once Estonia was occupied in 1940 and Standard Russian was very much present on the linguistic scene, as it is now; however, contact features have been preserved and bilingualism in Estonian and Russian continued.

The so-called newcomers form a rather different group of Russian-speakers. Under Soviet rule, migration of Russian-speakers to the Baltic republics was encouraged, while studying the local language was not compulsory and often remained a formality. Essentially, with a few exceptions, this group remained largely monolingual 
until 1991, when Estonia regained its independence. Estonian became a compulsory subject in all schools including those with a language of instruction other than Estonian, and a good command of the language is needed for working in the state sector as well as in some professions (physician, lawyer). Since 1991 one may observe a rapid bilingualisation of the younger generation of Russian-speakers. A comparison of CILC in the both varieties of Russian (Verschik, in preparation) shows that modern Russian is "catching up" with the old settlers' variety as far as structural change is concerned.

As for English, its appearance on the sociolinguistic scene coincided both with the regaining of independence and, as it is often put, return to the West with free travel, unlimited access to any kind of information and the advent of Internet. Unlike in the previous cases, there is a little direct contact with English speakers (some scholars call it weak contact situation, e.g. Zenner and Van De Mieroop 2017); still, one may argue that English-language virtual reality forms a kind of language environment comparable to the one of real life because of its massive presence and increasing importance.

Below I am going to briefly compare CILC in the three cases, using the metalanguage of CCF. As it follows from all the example above, all three situations are past Stage 1 on Thomason's scale since more than just lexicon is copied, yet differ in how far CLIC characteristic of Stage 2 has progressed.

\section{I. GLOBAL COPYING}

As far as GC is concerned, there are some minor differences between the three situations. First, semantic specificity may differ from context to context. Indigenous Russian has conventionalized GCs referring to agriculture, fishing, Estonian folk culture, etc. In the present day urban space where the majority of Russians dwells, fishing and agriculture are hardly relevant. Instead, Estonian terms from administration, banking, everyday realities, domains of higher education, management, accounting, etc. are globally copied. 
Nothing on copying of utterance modifiers in the old settlers' varieties is mentioned in the literature; however, this does not mean that copying of utterance modifiers from Estonian does not occur in this context. The main body of the literature originates from the 1960s-1970s, prior to the emergence of modern contact linguistics and the understanding of the importance of pragmatics in CILC. Modern Russian has copied a whole range of Estonian utterance modifiers (Zabrodskaja 2006); speakers have not substituted their Russian equivalents and the two sets are used in a parallel manner. Unlike in the situations described by Wertheim (2003), copying of utterance modifiers is not an indicator of a contracting variety.

Various English utterance modifiers are often being copied into Estonian; they appear in a variety of communicative genres: blogs, vlogs, Skype conversations, Facebook chat, podcasts, radio talk-shows (Aasaleht 2017; Igav 2013; Kask 2016; Ratt 2017; Rästa 2020; Roosileht 2013; Vaba 2010; Verschik, Kask 2019; Voolaid 2017). Similarly, it cannot be claimed that English utterance modifiers have replaced their Estonian equivalents.

Lexical items with a strong expressive connotation are rather often copied from English into Estonian: unglamorous, obsessed, weirdo, hype, boom, etc.; their appearance is rather prominent (Ratt 2017; Verschik, Kask 2019). Example (13) demonstrates how items that show the speakers' attitude are piled up and there is very little Estonian left in the utterance (other than that the main language of the conversation is Estonian):

(13) Estonian

\section{Oh my gosh, see difference though}

'oh my gosh, but this difference, though'

(modified from Ratt 2017: 25)

Cf. monolingual Estonian

Issand jumal, aga see vahe 
No special attention in the literature has been paid to Estonian expressive items in Russian other than discourse particles. Some pragmatic particles such as õudne 'awful', issand jumal 'oh my god', etc. fall under the category of items with a strong expressive connotation as well.

\subsection{SELECTIVE COPYING}

As stated above, it is useful to distinguish between different types of SCs: material, semantic, semantic combinational, combinational, and frequential copying.

Material copying refers to the realm of phonology. As described in Section 2, some sequences of phonemes in the old settlers' Russian have been replaced with Estonian-like sequences. In modern Russian, the changes are minor, i.e., only in the rendition of common internationalisms (Zabrodskaja 2006). No impact of English on Estonian phonology has been registered so far.

Semantic copying is registered in all three contact situations. Recall (2), where Russian krasivyj 'beautiful' is used in the meaning of Estonian ilus 'nice, beautiful, good, appropriate'. Similar examples can be found in the old settlers' Russian, for instance, deržat' 'to keep, to hold' is used on the model of Estonian hoidma 'to keep', 'to cherish', 'to look after' in the context of looking after small children (Heiter 1975: 103). The same happens in Estonian under the impact of English. Rather expectedly, semantic copying appears in common internationalisms; for instance, reaalne 'real, true', which is used in a smaller number of contexts than real in English, is gaining currency (Verschik, Kask 2019: 13).

As semantic copying is not indicative of structural change, there is no need to discuss it here in detail. Semantic combinational copying, however, is an intermediate group where some copies result in a new combination of items and new idiomatic meaning (loan translations in the proper sense in the terms of Backus and Dorleijn 2009) and some are on the border between just idiomatic meaning 
and structural change because the elements are not combinable in the monolingual variety (recall Example (4), an idiomatic analytical verb in modern Russian).

In all three sociolinguistic situations under consideration, idioms and fixed expressions are being copied. In addition, both old settlers' and modern Russian varieties give evidence of semantic combinational copying of compound items such as compound nouns and analytic verbs (Heiter 1977, Verschik 2008: 118-135, 146149, Zabrodskaja 2013: 86-87). Interestingly, Estonian compound nouns are subject to all types of copying, while analytic verbs are subject to selective combinational or mixed copying. This may be due to the general tendency described above whereby verbs are more often SCs rather than GCs. Usually, analytic items are reported as being attractive for copying (Johanson 2006: 25). No special research focusing on copying of analytic items from English into Estonian has been conducted, so nothing can be added on this point.

Combinational copying is copying of abstract features, such as order of elements, combinability rules (choice of preposition, case, etc.), which lead to structural change. Backus and Dorleijn (2009) distinguish this kind of CILC from loan translations, and label it "structural change". Although they do not use CCF terminology, this distinction is translatable into the metalanguage of CCF and is labelled combinational copying in the current article.

In both old settlers' and modern Russian, some instances of combinational copying are attested. Recall Example (5) from the old settlers' variety, which demonstrates copying of argument structure in a certain group of verbs ('to envy', 'to believe', 'to disturb', 'to help') and choice of direct object case (accusative in Russian), modelled on the Estonian partitive. This has not (yet?) been attested in modern Russian. Another change in argument structure that appears in both varieties is copying of separational government with verbs meaning 'to find', 'to purchase', 'to obtain', 'to ask', 'to look for' (from somewhere/ someone), etc. and of directional government with verbs 'to leave', 'to loose', 'to remain', 'to burry' (into somewhere). In monolingual 
Russian, such verbs have static government (see Nemčenko 1974 for examples in the old settlers' variety and Verschik 2006 on modern Russian). This is illustrated in Examples (14) and (15):

(14) old settlers' Russian

ot drug-a vzja-l-i den'gi

from friend-GEN take-PAST-PL money:ACC

'we/you/they took money from the friend'

(modified from Nemčenko 1974: 129)

Cf. monolingual Russian

$u$ drug-a vzja-l-i den'gi

at friend-GEN take-PAST-PL money:ACC

literally 'we/you/they took money that the friend'

Cf. Estonian

sõbra-lt võt-si-d raha

friend-ABL take-PAST-PL money:GEN

'you (sG)/they took money from the friend'

(15) modern Russian

étot polkovodec byl poxoronen sjuda

this commander was buried hither

'this commander was buried here'

(modified from Verschik 2006: 398)

Cf. monolingual Russian

étot polkovodec byl poxoronen zdes'

this commander was buried here

Cf. Estonian

see vägijuht maeti siia

this commander buried hither

The new pattern has not entirely replaced the old one, at least not in modern Russian. As for word order changes, there are optional changes in some genitive NPs where a noun genitive marking possessor precedes the head in the nominative, modelled on Estonian 
word order N GEN + N NOM (Zabrodskaja 2013, modern Russian). Apart from that, no word order changes have been attested in either Russian variety.

The situation of English-Estonian contacts differs in this respect. To date, no combinational copying has been attested (here utterances where a GC causes changes in morphosyntax are not considered).

As for copies of grammatical meaning/function, some of them do not "disrupt" grammar - a pattern is simply used in a larger number of semantic and pragmatic contexts than previously. Such changes have been attested in mas-construction modelled on the English progressive (recall Example 6). The same is probably happening with the Estonian poolt-construction, which corresponds to the English by in passive constructions:

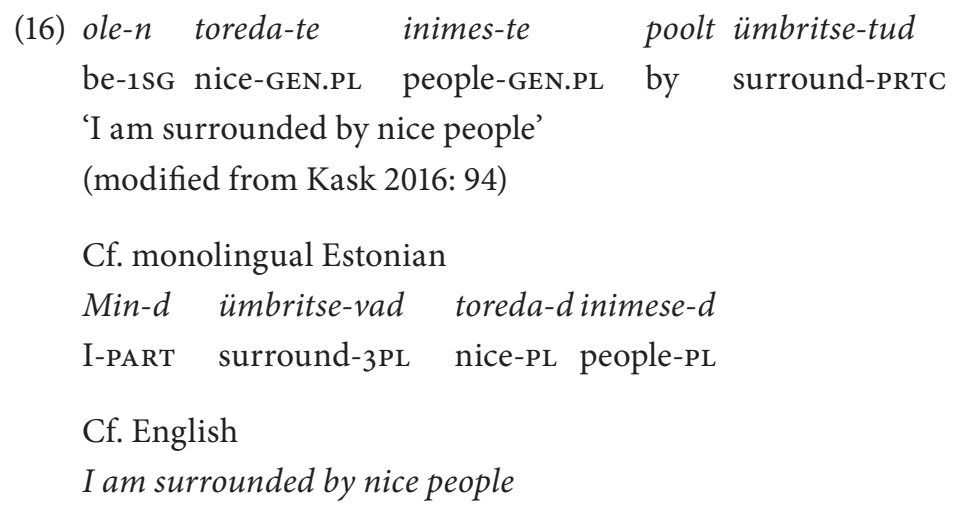

As noted, this is what Heine and Kuteva (2005) call a minor use pattern becoming a major use pattern. The increase in the number of contexts where a pattern may be used also implies change in frequency (frequential copying). However, under the heading of copying of grammatical meaning/function, there are instances that occur not only more frequently (i.e., where increase in the number of possible contexts of usage takes place) but also "disrupt" grammar. Consider generalization of the genitive as a case for partial object (possible in only a limited number of contexts in Russian) and for partial subject (impossible in monolingual Russian): 
(17) old settlers' Russian

Vsjak-ix jest' ljudej

all kind-GEN.PL be.3 people:GEN.PL

'there are all kind of people'

(modified from Murnikova 2012 [1962]: 57)

Cf. monolingual Russian

Vsjak-ije jest' ljudi

all kind-NOM.PL be:3 people:NOM.PL

'there are all kind of people'

Cf. Estonian

On igasuguse-i-d inimes- $i$

be:3 all kind-PL-PART people-PART.PL

'there are all kind of people'

As for Example (16), the use of the mas-form is not outright ungrammatical, although some speakers might ask whether it is appropriate in this context. In contrast, Example (17) sounds ungrammatical and unacceptable in monolingual Russian. No such changes have been attested in modern Russian.

There is some evidence that aspectual opposition in Russian is fading (under the impact of Estonian, which does not has grammatical aspect) in the old settlers' Russian (Mürkhein 1968) and similar claims have been made concerning modern Russian, although no examples of the latter have been provided (Külmoja 2004: 89). Deletion/non-distinction of difference can also be considered as a case of frequential copying.

\subsection{MIXED COPYING}

Due to problems of metalanguage, that is, lack of a label for what is called "MC", only a few MCs are attested in the old settlers' Russian. They are not described as a separate group but appear in some examples without any analysis. Mixed copying is productive in modern Russian and appears mainly in copies of Estonian compound nouns 
and analytic verbs (see Verschik 2016 for more detail). In Estonian, MCs from English appear in compound nouns (recall Examples (1) and (11)). At this stage, there is little information about MCs from English into Estonian, except for some examples in various studies (Aasaleht 2017; Igav 2013; Kask 2016; Ratt 2017; Rästa 2020; Roosileht 2013; Vaba 2010; Verschik, Kask 2019; Voolaid 2017).

Apparently, MCs may appear already at a relatively early stage of CILC, as in general they do not lead to restructuring. They may appear at the same stage as semantic copies and some instances of semantic combinational copies. More empirical data are needed in order to make more substantiated claims.

\section{Conclusions}

A general explanation of the order of CILC suggested by Thomason and Kaufman (1998) may be suggested. The juxtaposition of (1) meaning (particular vs. abstract), (2) various types of copying (with especial focus on SCs) and (3) CILC in the three contact situations according to Thomason's scale suggests that copying of grammatical meaning and combinability rules (patterns) occurs slower than copying of particular items (lexicon) because, apparently, more time is needed for abstract meaning to become entrenched (i.e., stored in one's cognition, see Backus 2012, 2015; Zenner et al. 2019). This has a cognitive nature: it is easier to grasp and process specific and pragmatically prominent elements and to incorporate them into one's usage. Of course, the division between specific and abstract meaning is not clear cut but rather there is a continuum. Items that are subject to semantic and semantic combinational copies in the case of idiomatic expressions have a less abstract meaning than semantic combinational copies of, say, analytic verbs, while the latter have a less abstract meaning than copies of grammatical functions that disrupt grammar and combinational copies (argument structure).

Before formulating conclusions, the following reservation has to be made. Dense copying where it is impossible to tell basic code 
from model code is not considered in Thomason's model or in CCF; it may be a special case where CCF is not particularly useful (this remains to be investigated). Still, it is clear that such dense copying (like Russian-Karelian, described in Sarhimaa 1999) does not emerge at Stage 1 and probably requires more time and cognitive effort to become possible. The conclusions are as follows.

First, in the terms of the scale proposed by Thomason and Kaufman (1988) and Thomason (2001), both old settlers' Russian and modern Russian are at Stage 2 (selective combinational copying and copying of functions is attested). The old settlers' variety is slightly "ahead": there is more Estonian impact on grammar, that is, more types of grammatical items where selective combinational copying occurs (i.e., patterns with more abstract meaning are subject to copying). Also copying of material properties (phonology) is slightly more ahead (probably, Stage 3) than in the modern Russian variety, where only common internationalisms may be realised in their Estonian version.

Second, as for the impact of English on Estonian, SCs appears mostly in isolated lexical items (semantic copying), fixed expressions (semantic combinational copying) but very rarely in grammatical patterns (that is, no combinational copying). Copying of grammatical meaning/function attested in Estonian (poolt- and mas-constructions) does not "disrupt" the grammar. Unlike in the Russian varieties, where selective copying appears also in particular classes of items (compound nouns, analytic verbs, argument structure in certain type of verbs), and not only in fixed expression with particular meaning, nothing of the kind is attested in Estonian under the impact of English. Apparently, copying of grammatical function that does not affect grammar may appear simultaneously with other types of selective copies that do not cause changes in grammar.

Third, the study considered only the connections between the types of copying, types of meaning (from particular to more abstract) and the stages of CILC, while no quantification for the case studies analysed above was provided, i.e., the share of each type of copies in 
a corpus. Still, it is useful to note that all studies on English-Estonian code-copying, albeit based on relatively small corpora, demonstrate that the share of GCs is always disproportionally large (80-90\%). The share of MCs and SCs is comparable; some studies attested more SCs than MCs (Aasaleht 2017, Ratt 2017, Roosileht 2013, Rästa 2020, Vaba 2010), while MCs slightly prevail in others (Igav 2013; Kask 2016; Verschik, Kask 2019; Voolaid 2017). Apparently, these figures show the current stage of CILC in Estonian under the impact of English.

Fourth, particular, expressive, and unique meaning is easily noticeable and probably does not need more cognitive effort to become entrenched. Abstract and general is more difficult to notice and to generalize; therefore, more exposure, experience of bilingual use and cognitive effort is needed for processing and entrenchment of patterns (for instance, use of a certain case with a certain preposition of verb). Thus, the explanation for why CILC in language maintenance starts with lexical items and only afterwards involves other domains is of a cognitive nature. Combination of cognitive aspects and CCF can potentially be useful for theory development, as CCF is descriptively accurate but does not provide sufficient explanation for why copying happens in a particular way. Different kinds of meaning are being noticed, processed and internalized at different speeds.

\section{REFERENCES}

Aasaleht, Helen 2017. Inglise-eesti koodikopeerimine Inglismaal ilmuvas ajalehes Eesti Hääl 1972., 1973., 1982. ja 1983. aastal [English-Estonian code-copying in the British Estonian-language newspaper Eesti Hääl in 1972, 1973, 1982 and 1983]. BA thesis. Tallinn: Tallinn University: School of Humanities.

Aikhenvald, Alexandra 2007. Multilingual fieldwork and emergent grammars. - Annual Meeting of the Berkeley Linguistics Society, 3-7. Available at: http://journals.linguisticsociety.org/proceedings/index.php/BLS /article/view/3513. 
Auer, Peter; Muhamedova Raihan 2005. 'Embedded language' and 'matrix language' in insertional language mixing: Some problematic cases. Italian Journal of Linguistics / Rivista di linguistica 17, 1, 35-54.

Backus, Ad 2001. The role of semantic specificity in insertional codeswitching: evidence from Dutch-Turkish. - Codeswitching Worldwide II. Ed. Rodolfo Jacobson. Berlin, New York: Mouton de Gruyter, 125-154.

Backus, Ad 2005. Codeswitching and language change: One thing leads to another? - International Journal of Bilingualism 9, 3/4, 307-340.

Backus, Ad 2012. A usage-based approach to borrowability. Tilburg Papers in Culture Studies. Paper 27. https://www.tilburguniversity.edu/research/ institutes-and-research-groups/babylon/tpcs/download-tpcs-paper-27. pdf.htm.

Backus, Ad 2015. A usage-based approach to codeswitching: The need for reconciling structure and function. - Code-switching Between Structural and Sociolinguistic Perspectives. Eds. Gerald Stell, Kofi Yakopo. Berlin: Mouton de Gruyter, 19-37.

Backus, Ad; Dorleijn, Margreet 2009. Loan translations versus code-switching. - The Cambridge Handbook of Linguistic Code-switching. Eds. Barbara E. Bullock, Almeida Jacqueline Toribio. Cambridge: Cambridge University Press, 75-94.

Backus, Ad; Verschik, Anna 2012. Copiability of (bound) morphology. Copies versus Cognates in Bound Morphology 2. Eds. Lars Johanson, Martine Robbeets. Boston, Leiden: Brill, 123-149.

Field, Fredric 2002. Linguistic Borrowing in Bilingual Contexts. Amsterdam: John Benjamins.

Haugen, Einar 1972. The Ecology of Language. Stanford: Stanford University Press.

Heine, Bernd; Kuteva, Tania 2005. Language Contact and Grammatical Change. Cambridge: Cambridge University Press.

Heiter, Helle 1968 = Xejter, Xelle. Ob éstonskom vlijanii na sistemu glasnyx fonem $v$ russkom govore Ijzaku [Estonian impact on the vowel system of the Russian dialect of Iisaku]. - Sovetskoje finno-ugrovedenije 4, 2, 103-108.

Heiter, Helle 1975 = Xejter, X. I. Ob otraženii mežjazykovyx kontaktov v leksičeskoj sisteme odnogo iz russkix govorov severo-vostočnoj Éstonii 
[On the manifestation of language contacts in the lexical system of a Russian variety in the north-east of Estonia]. Trudy po russkoj i slavjanskoj filologii XXV, 95-103. Tartu: Tartu University Press.

Heiter, Helle 1977 = Xejter, X. I. Kal'kirovanije kak vid projavlenija leksičeskoj interferencii [Calquing as a type of manifestation of lexical interference]. Trudy po russkoj i slavjanskoj Filologii 27. Tartu: Tartu University Press, 200-206.

Igav, Reet 2013. Inglise-eesti koodikopeerimine Facebooki vestlustes [English-Estonian code-copying in Facebook conversations]. MA thesis. Tallinn University, Institute of Estonian Language and Culture.

Johanson, Lars 1992. Strukturelle Faktoren in türkischen Sprachkontakten (Sitzungsberichte der Wissenschaftlichen Gesellschaft an der J. W. Goethe-Universität Frankfurt am Main, 29: 5). Stuttgart: Steiner.

Johanson, Lars 1993. Code-copying in immigrant Turkish. - Immigrant Languages in Europe. Eds. Guus Extra, Ludo Verhoeven. Clevedon, Philadelphia, Adelaide, 197-221.

Johanson, Lars 1999. The dynamics of code-copying in language encounters. - Language Encounters across time and space. Eds. Brent Brendemoen, Elizabeth Lanza, Else Ryen. Oslo: Novus, 37-62.

Johanson, Lars 2002a. Contact-induced linguistic change in a code-copying framework. - Language Change: The Interplay of Internal, External and Extra-Linguistic Factors (Contributions to the Sociology of Language 86). Eds. Mari C. Jones, Edith Esch. Berlin: Mouton de Gruyter, 285-313. Johanson, Lars 2002b. Do languages die of structuritis? On the role of codecopying in language endangerment. - Italian Journal of Linguistics/ Rivista di Linguistica 14, 2, 249-270.

Kask, Helin 2016. English-Estonian copying in Estonian blogs. - Philologia Estonica Tallinnensis 1, 80-101.

Kecskés, Istvan 2006. On my mind: thoughts about salience, context and figurative meaning from a second language perspective. - Second Language Research 22, 2, 1-19.

Keevallik, Leelo 2006a. Keelekontakt ja pragmaatika [Language contact and pragmatics]. - Teoreetiline keeleteadus Eestis II [Theoretical linguistics in Estonia II]. Eds. Ilona Tragel, Haldur Õim. Tartu: Tartu University Press, 85-96. 
Keevallik, Leelo 2006b. Pragmaatiliste partiklite laenutüübid rootsieesti keeles [The types of pragmatic particles borrowing in Swedish Estonian]. - Võro Instituudi toimõndusõq 18, 116-133.

Külmoja, Irina 2004. O sovremennom sostojanii jazyka russkoj diaspory Éstonii [On the present situation of the language of the Russian diaspora in Estonia]. - II Meždunarodnyj kongress issledovatelej russkogo jazyka. Trudy i materialy. Moscow: Moscow State University, 84-90.

Matras, Yaron 1998. Utterance modifiers and universals of grammatical borrowing. - Linguistics 36, 2, 281-331.

Matras, Yaron 2009. Language Contact. Cambridge, New York: Cambridge University Press.

Matras, Yaron 2012. An activity-oriented approach to contact-induced language change. - Dynamics of contact-induced language change. Eds. Claudine Chamoreau, Isabelle Léglise. Berlin: Mouton de Gruyter, $17-52$.

Matras, Yaron; Sakel, Jeannette 2007. Investigating the mechanism of pattern replication in language convergence. - Studies in Language 31, 829-865.

Metslang, Helle 2006. Predikaat ajastut kogemas [Predicate experiencing the epoch]. - Keel ja Kirjandus 9, 714-727.

Muysken, Peter 2000. Bilingual Speech: A Typology of Code-mixing. Cambridge: Cambridge University Press.

Murnikova, Tatjana 2012 [1962]. Opisanije russkogo govora Piirisaara [A description of the Russian variety of Piirisaar]. - Acta Slavica Estonica I. Očerki po istorii i kul'ture staroverov Éstonii III. Tartu: Tartu University Press, $40-59$.

Mürkhein, Veera 1968 = Mjurkxejn, Vera. 1968. Vlijanije éstonskogo jazyka na razvitije vidovyx otnošenij v russkom govore s. Mexikorma Éstonskoj SSR [The infulence of the Estonian language on the development of the category of aspect in the Russian dialect spoken in the village of Mehikoorma in the Estonian SSR]. - Sovetskoje finno-ugrovedenije IV, 3, 175-180.

Nemčenko, E. V. 1974. Iz nabljudenij nad sintaksisom russkogo govora s. Mexikoorma Tartuskogo r-na Éstonskoj SSR (k voprosu o pronicajemosti sintaksičeskoj sistemy govora pri vozmožnosti inojazyčnogo vlijanija). [Some obervations on the syntax of a Russian variety in the 
village of Mehikoorma of the Tartu region in the Estonian SSR (the question of penetrability of syntactic system in the conditions of the possibility of foreign language influence).] - Dialektologičeskij sbornik. Materialy IV dialektologičeskoj konferencii po izučeniju govofov i jazykovyx kontaktov v Pribaltike. Oktjabr' 1972. Vilnius: Vilnius University Press, 125-131.

Ratt, Silja 2017. Inglise-eesti koodikopeerimine Maria Rannavälja vlogides [English-Estonian code-copying in Maria Rannavälja's vlogs]. BA thesis. Tallinn University: School of Humanities.

Roosileht, Helin 2013. Inglise-eesti koodikopeerimine blogides [EnglishEstonian code-copying in blogs]. MA thesis. Tallinn University: School of Humanities.

Rästa, Liisi 2020. Inglise-eesti koodikopeerimine taskuhäälingus "Tissident" [English-Estonian code-copying in "Tissident" podcast]. MA thesis. Tallinn Unviersity: School of Humanities.

Sarhimaa, Anneli 1999. Syntactic transfer, contact-induced change, and the evolution of bilingual mixed codes: Focus on Karelian-Russian language alternation. Helsinki: Finnish Literature Society.

Thomason, Sarah Grey 2001. Language Contact: An Introduction. Edinburgh: Edinburgh University Press.

Thomason, Sarah Grey 2007. Language contact and deliberate change. Journal of Language Contact 1, 41-62.

Thomason, Sarah Grey; Kaufman, Terence 1988. Language Contact, Creolization, and Genetic Linguistics. Berkeley: University of California Press.

Vaba, Marja 2010. Inglise-eesti koodikopeerimisest Tallinna Skype’i kontori kahe vestlusgrupi näitel [English-Estonian code-copying on the example of two chat groups at Skype Tallinn office]. MA thesis. Tallinn University: Institute of Estonian Language and Culture.

Van Hout, Roebert; Muysken, Pieter 1994. Modelling lexical borrowability. - Language Variation and Change 6, 1, 39-62.

Verschik, Anna 2006. Convergence in Estonia's Russian: directional vs. static vs. separative verb. - International Journal of Bilingualism 10, 4, 383-404.

Verschik, Anna 2008. Emerging bilingual speech: from monolingualism to code-copying. London, New York: Continuum. 
Verschik, Anna 2016. Mixed copying in blogs: evidence from EstonianRussian language contacts. - Journal of Language Contact 9, 186-209.

Verschik, Anna 2019. English-Estonian code-copying in blogs: combining a contact linguistic and cognitive approach. - Cognitive Contact Linguistics. Eds. Eline Zenner, Ad Backus, Esme Winter-Froemel. Berlin: Mouton De Gruyter, 51-80.

Verschik, Anna. In preparation. Impact of Estonian on local Russian now and then: similar or different?

Verschik, Anna; Kask, Helin 2019. English-Estonian code-copying: comparing blogs and vlogs. Applied Linguistics Review. https://doi.org/10.1515/ applirev-2019-0028.

Voolaid, Helena 2017. Inglise-eesti koodikopeerimine raadiojaama Sky plus hommikuprogrammis [English-Estonian code-copying in radio Sky plus morning program]. BA thesis. Tallinn University: School of Humanities.

Wertheim, Suzanne 2003. Linguistic Purism, Language Shift and ContactInduced Change in Tatar. PhD thesis. University of California, Berkeley.

Zabrodskaja, Anastassia 2006. Eestivene keel(evariant): kas samm segakoodi poole? [Estonia's Russian language (variety): a step towards fused lect?]. - Keel ja Kirjandus 9, 736-750.

Zabrodskaja, Anastassia 2013. Morphosyntactic contact-induced language change among young speakers of Estonian Russian. - The Interplay of Variation and Change in Contact Settings. Eds. Isabelle Léglise, Clodine Chamoreau. Amsterdam, Philadelphia: John Benjamins, 77-106.

Zenner, Eline; Backus, Ad; Winter-Froemel, Esme 2019. Cognitive contact linguistics. Placing usage, meaning and mind at the core of contactinduced variation and change. - Cognitive Contact Linguistics. Eds. Eline Zenner, Ad Backus, Esme Winter-Froemel. Berlin: Mouton De Gruyter, 1-20.

Zenner, Eline; Van De Mieroop, Dorien 2017. The social and pragmatic function of English in weak contact situations: Ingroup and outgroup marking in the Dutch reality TV show Expeditie Robinson. - Journal of Pragmatics 113, 77-88. 


\section{RESÜMEE}

\section{SELETADES KONTAKTIDEST JOHTUVATE MUUTUSTE TEKKIMISE JÄRJEKORDA}

Vastavalt Thomasoni ja Kaufmani (1988) üldistustele, keelekontaktidest johtuv keelemuutus (keelesäilitamise puhul) algab sõnavarast, seejärel levib semantika, fonoloogia ja perifeerse morfosüntaksi tasandile; vastavas sotsiolingvistilises olukorras võib teise keele mõju põhjustada olulise morfosüntaktilise ümberkorralduse. Niikaua pole keegi pakkunud seletust, miks muutuste järjekord on just selline. Artikkel "tõlgib" Thomasoni ja Kaufmani (1988) laenamisskaala koodikopeerimise mudeli metakeelde (Johanson 1992). Selle mudeli terminoloogia tekitab arusaama, et kognitiivne mehhanism (kopeerimine) on sama kõigi muutuste taga, ainult et leksikaalsetel ühikutel ja grammatilistel joontel on erinev tähenduse tüüp (konkreetne vs. abstraktne) ja seetõttu eri tähendused produtseerivad eri koopiatüüpe. Spetsiifiline tähendus soodustab täielikku kopeerimist, abstraktne (grammatiline tähendus) aga valikulist kopeerimist. Arvatavasti nõuab abstraktsemate tähenduste töötlus, kinnistumine ja konventsionaliseermine rohkem aega. Koodikopeerimismudel on mugav sellepoolest, et kirjeldab ühesuguses terminoloogilises raamistikus kõiki muutuseid (sõnavaras, semantikas ja morfosüntaksis). Kui vaadata kopeeritud elementide tähendust, siis on näha, et spetsiifiline ja ekspressiivne tähendus soodustab täielikku kopeerimist ning abstraktsem (nt grammatiline) tähendus soodustab valikulist kopeerimist. Ilmselt nõuab abstraktsema tähenduse töötlemine, kinnistumine ja konventsionaliseerumine rohkem aega. See seletab, miks struktuurimuutused (valikulised koopiad) tekivad hiljem.

Võtmesõnad: keelekontaktidest johtuv keelemuutus, koodikopeerimine, struktuurimuutus, eesti keel, vene keel, inglise keel

Anna Verschik is professor of general linguistics at Tallinn University. Her interests include contact-induced language change, multilingualism, and Baltic sociolinguistics. anna.verschik@tlu.ee 